\title{
Freedom and Individuality in Githa Hariharan In Times of Siege
}

\author{
Aayushi Sharma
}

M.A. Student (English Literature), School of Language and Literature, Shri Mata Vaishno Devi University, Katra, Jammu \& Kashmir, India

\begin{abstract}
The motivation behind this research was how feminist elements have been reflected in works of Indian women writers like Anita Desai, Githa Hariharan, Meena Alexander etc. The present research work is a critical study of Githa Hariharan In Times of Siege from the perspective of feminism and the study aims to project and interpret the experiences of protagonist, from the point of feminine consciousness and sensibility. The objective of this research is to explore the rejection of patriarchal ideology and maledominated culture in Githa Hariharan's novel. The research will examine her progressive ideas on women autonomy through education and self-employment. The result will be formulated on the basis of marginalization and inferiority of females, neglection of women in patriarchal society and gender disparity and longings of women in androcentric setup.
\end{abstract}

Keywords - gender, feminine, marginalized, disparity, autonomy.

"Strengthen the female mind by enlarging it, and there will be an end to blind obedience".

1. A Vindication of the Rights of Woman written by the eighteenth century British proto-feminist Mart Wollstonecraft, is one of the first work of feminist philosophy. It was originally published in 1792. In it, Wollstonecraft replies to those educational and political theorists of the eighteenth century who did not have faith in women should have an education. She claims that women should have an education appropriate with their position in society, appealing that women are important to the country because they educate its children and because they could be "companions" to their husbands, rather than simple wives. Instead of seeing women as ornaments to the society or property to be dealt in marriage, Wollstonecraft sustains that they are human beings deserving of the equal essential rights as men. While Wollstonecraft does call for equality between the sexes in specific parts of life, such as morality, she does not clearly state that men and women are equal.

2. The Subjection of Women is an essay by English philosopher, political economist and civil servant John Stuart Mill published in 1869. His close friendship with Harriet Taylor, whom he later married in 1851. Mill argument is simply an extension to women of the enlightenment belief and women's subordination was a barbarous relic of past. Women appeared inferior to men in many way but this was to result of social pressure and faulty education. He claimed that women must be given same opportunities as men, only then they will know their true ability. He suggested that women's legal servitude in marriage must be abolished. They must be allowed free access to education and employment and they should also be allowed both to vote and hold political office. Mill was criticized for betraying the very principles on which his feminism was based. Although he talked about individual freedom for women but his ideology for married women remain restricted to separate spheres. According to him, women is free to follow the career of her own choice and should not be forced into marriage claiming it to be an institution of economic security.

3. The Second sex is a1949 book by French existentialist Simone de Beauvoir, in which the author deliberates the action of women through history. The Second Sex is frequently stared as a main work of feminist philosophy and the starting point of second -wave feminism. She argues that man is considered as default, while woman is considered the 'other". Beauvoir defines the relationship of ovum to sperm in numerous creatures leading up to the human being. She describes women's demotion to the species in terms of reproduction, associates the physiology of men and women, concluding that values cannot be constructed on physiology and that the facts of biology must be 
observed in light of the ontological, economic, social and physiological situation.

4. The Feminine Mystique is a book written by Betty Friedan which is broadly ascribed with sparking the start of second -wave feminism in United States. It was published on February 19, 1963. In 1957, Friedan was asked to conduct a survey of her former Smith College classmates for their fifteenth anniversary meeting; the results, in which she originate that many of them were unhappy with their lives as housewives, encouraged her to begin investigation for The Feminine Mystique, conducting interviews with other suburban housewives, as well as investigating psychology, media and advertising. She first intended to publish an article on the topic, not a book, but no magazine would publish her article.

5. Sexual politics is a 1970 book by Kate Millett based on her $\mathrm{PhD}$ thesis. The book is observed as a classic of feminism and one of radical feminism's key texts. Millett argues that "sex has often ignored political aspect" and goes on to discuss the role that patriarchy plays in sexual relations, looking particularly at the works of D.H.Lawrence, Henry Miller and Norman Mailer. Millett argues that these authors view and discuss sex in a patriarchy and sexiest ways.

Githa Hariharan's novel In Times of Siege which defines common events in New Delhi occurred in 2000. Staff meetings, lesson modules, a halfhearted little affair with a colleague is the blank but comfortable life of Shiv Murthy, a history teacher in an open university. Shiv is the main character of the novel further gets intensified due to the internal conflicts. In the University, Prof. Shiv is the medieval history professor. Shiv who is predictable as a secular reformist. About this character it has been pointed that,

"Professor Shiv Murthy is a professor of medieval Indian history of correspondence University in New Delhi. $\mathrm{He}$ is also in some sense deeply and emotionally stunted by a childhood experience, the sudden disappearance of a father who had been a frustrated Indian freedom fighter. Shiv Finds himself in hot water when the Hindu fanatics up on a series of lesson he's written on a twelfth century reform figure named Basava". (Web 10-04-2018)

An outspoken young woman with a broken knee comes into his life and tries it upside down. During this time, Hindu extremists attack his writings on Basava, the reformer poet. When fundamentalists lands on his doorstep, shiv discovers that the ideas he had inherited about history, nations, and patriots change in the course of time. The bitter realities are evoked by Githa Hariharan in this novel. Moreover, Githa Hariharan's feminist ideas are indirectly reflected in this novel. Krishnan Das and Deep Chand patra have rightly pointed:

"Female voices who have wielded the writer's pen to present forth literature which not only highlight women's plight in society, but have also enriched the field with brilliant narratives, styles, techniques and themes, enchanting generations of readers, and immortalizing their own

Agenda in penning their works". ( Das Krishnan i) Githa Hariharan picks up her protagonist from the academe for the first time. Shiv Murthy, a middle aged and mild mannered history professor of Kasturba Gandhi Open University, Delhi, visits Meena, the daughter of his childhood friend Sumathi, who has broken her leg in an accident. He takes her, in the capability of her local guardian, to his house for a few days. In the absence of his wife Rekha, he makes all preparations for Meena's stay in his study room and helps her in daily routines. Moreover, she is a sociological student of Kamala Nehru University , studying about the women who are exaggerated by anti-Sikh riots after Indira Gandhi's murder in 1984.Being an ' activist', she often attends meetings and talks of causes and street theatre, gender and invites capture with the comfort of a expert. (Hariharan 31). Meanwhile, the Professor of History is trapped up in a argument over his lesson on twelfth century poet and social reformer Basava. Since it hurts the thoughts of the Hindu watchdog group 'Ithihas Surksha Manch', they find liability with Shiv for his planned falsification of Indian medieval history and demand a confession for that. Meena's information, the Professor neither apologizes nor removes his lesson. To counter the attack of the Manch, Shiv comes up with an action idea in discussion with all his classmates. At this stage, while Shiv annoying to originate emotive support from his freedom fighter father's teachings and his private tradition, Meena spreads her full support to shiv by connecting her friends-Amar who has been a devoted member of several citizens group and his friends.

Afterward, Shiv is informed by his colleague Menon that his lesson has been referred to a Review Committee and his resignation is evident. But, Meena is moderately against to this. She makes all preparations for a Press conference with the support of her friends. At this moment, the university calls back medieval history lessons booklets from students. The Manch president and Vice president call for the revival of Hindu courage. On the other side, famous Leftist historians convict the acts of Kasturba Gandhi University, and promotion their fight against Hindu organizations. 
Meena, with the help of Amar and his essential friends, organize a TV show; make a booklet attacking RSS and their ideologues.

At the KGU campus, a mob tries to attack Shiv, and his colleague Menon fortunately protects him but his office room is completely destroyed. As a consequence, the fight between the Leftists and the Right wing intensifies. Shiv collects many letters from Manch supporters. He also receives a life threat to his wife and daughter from unidentified caller. He gets many newspaper clippings, and letters to editor complaining against his distortion of a historical fact In reply, some like -minded people have accumulated to plan for a public meeting and a rally. The Vice Chancellor in a TV interview expresses his concern about the security of the University. He writes a letter to Shiv updating him that the current incident has brought disrespect to the university. Shiv's father's thinking becomes a walking stick for him. Meena and Shiv go to the doctor where the cast is removed finally Meena leaves for hostel accompanied by Amar and the walking stick of Shiv's father.

Shiv is a common man who is content in his daily life and used and to avoid conflict whenever possible. But Meena, a student belonging to the younger generation is able to infect interest in this middle-aged thoughtful professor Murthy and established a kind of growing in him when his personal and professional lives are shaken. Concluded him Hariharan portrays how even 'the cautious, silent, middle class' voices will be raised up during the times of siege.

On campus, we come across politics mainly with student union, election of leaders, fights between different student groups during elections, organizing dharanas and making rallies etc. We also find students' relationship to different political parties and other social, religious outfits fight in groups leading to bloodshed and cause police interference or action. Students organize and conduct programs created on the call given by their political and religious or community advisors. We challenge some of the above things occur at the fictitious KGU campus created by Hariharan. Suddenly, she has brought a political and social problem, worthy of debate at national and international levels to a university campus. To a question on why Githa chose the university as the scene of action, she said-

"Well, for me the campus is not central but the outside. If in a university set-up, debate, free and frank, is stifled, then that show

the insidious nature of communal forces". But does it not show that academic culture and values are already atrophied had already become somewhat redundant? "Well, yes, I do recognize and foreground the fact that there is a return to a sense of fear, persecution and ghettoization. There is the atrophy of intellectuality and a decline of the romantic veneration of the teacher figure". ( The Hindu)

This exposure clarifies she is well aware of the demeaning values in academics and decline in the value of a teacher. She also wants to present the influence of external common and political forces on academic set up as well as debate. The contribution of students in the controversy and their activities further exaggerate the condition to the end. It completely takes the shape of political war. Releasing brochures and pamphlets, calling for urgent meetings, staging dharnas, organizing rallies and planning processions, shouting slogans, displaying placards, making public statements by mocking the leaders and their philosophies on either side, media making the crazy news, telecasting interviews on TV, destroying offices, brick batting, is the image one spectators in the novel. The KGU campus is usually free from regular students and class work as it offers courses in reserve manner. But to our surprise we see the gangs attacking professor's office. This is an example of interference of external world into university campuses. The campuses have become holes for all social and anti-social activities. We also come across activities and activists of both sides Manch and the leftist groups.

Hariharan clearly wanted to draw devotion to what essentially amounts to thought controlling, to exaggerate the chilling consequences of political control over intellectual freedom, feels Madhuparana Mitra. In times of siege, the protagonist Shiv Murthy becomes the mouth piece of the author's ideological position (Mitra 141). But one can see the shadow of novelist Hariharan in the character of Activist Meena, Hariharan is very much energetic in human rights activities. Meena also works for the women who were pretentious in Anti Sikh riots however, she often attends meetings and talks of causes and street theatre, gender and invites arrest with the comfort of expert as Hariharan in actual life.

The novel is constructed on ideological war occurred in the late 90's in twenty century in India. When National Democratic Alliance came to control in 1999, the government tried its level best to change the then established Marxist minded intellectuals with right wing scholars in curriculum growth agencies at the nation level. The main conflict of the story i.e. the imaginary Shiv's experience is similar to that of a real life Play-Wright H.S. Shiva Prakash, whose play on Basava was convicted by self-appointed 
protectors of history some years ago. In the same lines, the performance of medieval Basava, in History study material, leads to argument in the novel.

Separation among the staff is obviously seen as Left and Right wings, Dr. Arya is the Right while the Left by the Dr. Menon and others. Professor's support and addressing different ideologies confront each other and make the peaceable university, a place of controversy. It is obvious at the subdivision, in a staff meeting, Dr. Arya raises oppositions about removal of a history lesson in an important section: 'problems of the country and their Solutions' by Dr. Menon. Meena encourages Shiv to drop into her personal world of risk, danger, choice and commitment. When the fight among Left and Right wings grimes up, supporters from both sides like Guru Khote, Prof. Fraudely, Arya, and Ameer Qureshi, all get involved in the fight. Meena affects her glowing thought-out plan by preparing Shiv for a TV show and later some twenty like-minded people have gathered to plan for a public meeting and a rally.

Hariharan has expressed her lineage of Marxism in the interview. She says that she is a feminist and with several other things. It is revealed indirectly in an interview as:

"Am I a writer particularly concerned with "women's issues"? And am I a feminist? ...And anyway, however you define yourself, all our work is

Informed in some way or the other by feminism, along with the ideas of Freud and Marx. So...I am a writer (as opposed to a woman writer)

Who is a feminist, along with several other things!" Thus all these research in treatise investigation bring to us three evidences as follows:

1. Githa Hariharan is continuously pure in describing liberal ideas whereas, she is an smart observer of the cultural problems.

2. The second aspect of this discourse study tells that religious writing which targets another religion must be evaded because they are complications in the social peace.

3. The third important aspect is that progressive groups in the society must be prepared and they have to fight the communal forces.

\section{CONCLUSION}

Githa Hariharan being a winner of liberal ideas has continued her school of feminism in this political novel also. She was prospered after the common riots in Gujarat. She has pointed that there is a fewer space for debate in India and elsewhere. Later she has complained against this bitter truth. The above instances clear the verbal attack and its brutality on author's ideological challengers. When the novel was on middle two historians were attacked in India for their historical writings and that illustrated the attention of Githa Hariharan. In this novel the ideological war between the Left and Right wings and live politics on campus. As campus is a small form of real world, it also imitates politics of real world in toto. The traditional view of Indian society and protest against the oldfashioned values has been reflected by the author. Githa Hariharan, the author of the novel, is expert sufficient to describe campus life and campus politics in attractive and articulate manner for her different readership.

\section{REFERENCES}

[1] Wollstonecraft, M. (1792). A Vindication of the Rights of Woman: With Strictures on Political and Moral Subjects.

[2] Beauvoir, S. (1949). The Second Sex.

[3] Friedan, B. (1963). The feminine mystique. New York: W.W. Norton.

[4] Mill, J. S. (1869). The subjection of women. New York: D. Appleton and Company.

[5] Millett, K. (1970). Sexual politics. New York: Ballantine Books.

[6] Das, K. and Patra, D. (2012). Studies in Women Writers in English. New Delhi: Commonwealth Publishers, p.278.

[7] Githa Hariharan, [online] Available at: http://wwwcurledup.com/githaint.html [Accessed 16 Apr. 2018]. 